\title{
Local Governor's Leadership Skills in Local Development Perspective
}

\author{
Kwang Hee Lee*
}

\begin{abstract}
This study analyzes the leadership and the skills that third-term local governors who were reelected in the 2002 Korean local elections showed in the process of developing a vision and strategy for their local development during their first and second terms of office. Following Bass's (1985) two-factor model transformational and transactional theory, this paper classifies leadership skills into three types of knowledge-using skills, interorganizational behavioral skills and Interpersonal skills and examines them. The result shows that 10 out of 13 local governors preferred transformational leadership to transactional leadership. Considering only leadership skills, most governors preferred knowledge of the local environment, communication/persuasion/negotiation skills, and self-confidence and self-esteem. Moreover, 12 local governors utilized interorganizational behavioral skills more than the other two types. In particular, 10 local governors tried to change relations with the help of the public and specialists, and win cooperation and support through a communication/persuasion/negotiation strategy that utilized interorganizational behavioral skills. Thus, the paper argues that for a successful execution of services, interorganizational behavioral skills are the most important skill.
\end{abstract}

\section{INTRODUCTION}

With the rebirth of the local autonomy system in 1991, local governors have been elected by popular vote every fourth year. A total of 16 heads of upper-level local governments and 232 heads of lower-level local governments were elected in the Korean local government elections of 1995, 1998 and 2002. These three elections revealed that local government constituents paid a lot of attention to local elections.

Approaches to previous studies on local governor's leadership have developed progressing from trait theory to behavioral theory to situational theory. 1) Leadership research in Korea has

\footnotetext{
* Senior Research Fellow, Knowledge Center for Public Administration and Policy, Graduate School of Public Administration, Seoul National University

1) Trait theory focuses on a leader's personality and qualities to discover the leader's universal characteristics. Behavioral theory accounts for effectiveness of leadership through leader's behavior. Situational theory however, criticizes and adjusts the two theories
}

progressed and become more active since the rebirth of the local autonomy system and the local government election in 1995. Earlier studies focused on what roles local governments should play after the revival of the local autonomy system. These studies included an emergence of the heads of local governments and a change of local government's power structure (Kim, 1995; Kim, 1996), local governor's crucial roles in a changing environment (Kim, 1994; Lim \& Cho, 1996) and the achievements of locally driven development and decentralization (Seong, 1995). Studies on leadership presented since 1995 have progress to studying the effects on local governor's leadership (Lee, 1998: 147 161), empirical studies on local governors' leadership behaviors and effectiveness (Lee, 1999: 273 286; 2000: 139 160) and local governors' behavioral analysis in the policy-

and focuses on the introduction of situational variables. That is, the effectiveness of leadership is determined by leader's own behavioral style as well as by the situation in which leadership is exercised. 
making process (Lee \& Jung, 1999: 287 308). That is, the studies analyzed how local governors showed their leadership by mobilizing various factors in the changing public administration environment. The results emphasized the importance of the governors' roles in all situations and showed that governors exercised their leadership effectively within the limitations of their resources and power.

However, previous studies are insufficient to account for the features of the local governor's leadership exercised for regional development after the rebirth of the local autonomy system. With this in mind, this study analyzes what leadership is exercised and what skills are used in the process of developing out and executing a vision and strategy within the local autonomy system.

\section{THEORETICAL DISCUSSION AND ANALYSIS MODELS}

\section{The Concept of a Local Governor's Leadership}

Denhardt \& Stewart (1992: $37 \sim 38$ ) state that leadership typically involves helping the members of a group become aware of a new direction in which they wish to move, which in most cases is already present in their subconscious. In this sense, leadership includes the following characteristics. First, leadership is a capacity of the group, a resource that lies within the group and must be activated for the group to fill its potential. Second, lcadership develops and reshapes the consciousness of organizational members and makes possible the sharing and integration of a variously divergent vision. Third, leadership behavior presents new directions that are determined by the emerging interests expressed by the group members. Thus, leadership behavior without the consideration of reciprocity will be scparated from organizations. Eventually, such leadership behavior will ultimately result in the breakdown of reciprocity.

However, a local governor's leadership should not only be considered on the above-mentioned features of leadership but also on the ability to adjust to and induce a change to the local autonomy's administration. 2)

Actually, since the revival of the local autonomy system in 1991, local governors have faced a strong demand for change and administrative innovation, as well as for adjustments to established internal organizations. These situations call for the enhancement of the local government's autonomy and creativity, and the local governor's leadership ability to forge ahead balancing changes to the local autonomy's administration in concert with local development. Thus, a local governor's leadership cannot be separated from the development process of a local society and should be connected to a social context that understands the dynamics of the local autonomy. Separation from local development and dependence upon personality and quality alone, would likely result in failure. When considered on personality and quality, leadership research is helpful for understanding the nature of leadership, but does not provide the necessary information to develop and prepare for leadership functions.

Thus, a local governor's leadership may be defined as an ability to understand and realize a vision and goal of local autonomy through a connection with its inner and outer environments within limitations as a unique process beyond personality. Among the features of a local governor's leadership are the following. First, it should resolve pending local issues and present a vision for a local development. Second, it should effectively manage a local government's interorganizational relationship. Third, it should motivate public officials and harmonize the organizational atmosphere. 3 )

2) Kim (1995), Lee (1998), and Lee $(1999,2000)$ claim that local governors' leadership is generally influenced by situational factors such as their personality, local politics, participants and socio-economic conditions. 


\section{Types of Local Governors' Roles}

Local governors' roles are prescribed institutionally by the Local Autonomy Act, and are involved with executing public affairs for administration of the local autonomy and local development. However, there are limits to understanding local governor's leadership that devolve from the former institutional viewpoint. Above all, local governor's roles, as presented in previous studies, run as follows. The research of Lee (1995) classifies local governor's roles as political, administrative, and leadership following Clark and Stewart, while Hong (1999) classifies the roles as political, administrative and executive. Non-Korean research allocates roles that are more diverse. Some scholars have proposed roles consisting of entrepreneurship, caretaking, trustee-managing, ceremonial, individual, executive, crusading, bossing, brokering, reforming, etc. (Park \& Lee, 2002: 373 375). In previous studies, the characteristics of local governors' role classification are found at the situational level of most organizations rather than in individual trait theory (Park \& Lee, 2002: 377). This approach should show that the study on local governors' leadership should consider both similarities and differences, depending on the situational level. In this sense, popularly elected local governors differ from their appointed counterparts because they are elected by popular vote in the local government election. Thus, they should develop their own leadership skills to meet residents' various needs and effectively manage a local government's interorganizational relationship. Pack (2002) refers to a new style of local autonomy administration, which is suitable for the changing environment of popularly elected local autonomies, as a governance leadership. This presupposes that

3) Lee (1998:149) considers a local governor's leadership from the same perspective. That is, it is evaluated in the process of executing the leader's personal vision in the face of participants' conflicts on how to resolve local pending issues. popularly elected local governors are different from appointed counterparts.

Recently, local governments have been urged to pursue radical change and reform. A goal of President Rho Moo-hyun's government (called 'Participatory Government') has been for local autonomies to have increased power to cope with a new environment of local autonomy administration, meet residents' needs as rapidly as possible, and achieve decentralization and balanced development. Importantly, they should strengthen leadership to pursue change and reform and to effectively adjust to themselves. In addition, Bennis \& Nanus (1985), Storey (1992) and Burns (1978, 1992) emphasize that leadership is needed to pursue change of the local autonomy's administration and local development and enhance autonomy, flexibility and creativity. Features of such leadership are closely related to the level of transformational leadership dealt with in Bass (1985) and Bass \& Avolio (1994). Thus, this study, which investigates popularly elected local governors' leadership, follows Bass's two-factor model, and distinguishes between transformational and transactional leadership and takes into account the leadership skills utilized in the leadership process. ${ }^{4}$ )

\section{Analytical Framework of Leadership skills}

Bass's (1985) two-factor model presented transformational and transactional leadership as taking a similar interest in orienting organizations in a new direction but are different in methodology. Transformational leadership is change-oriented leadership. It chiefly induces a change of values and faith, a practice of justice by entire organizations and an integration of values, a presentation of the conviction of moral justness, or an innovative

4) According to Bass \& Avolio (1990), transformational leadership consists of charismatic leadership, inspired leadership, individualized consideration and intellectual stimulation. 
change in organizations. Moreover, it makes a point of being creative, having moral standards or motivating through an interaction with followers (Lee, 1994; Lee, 1999).

In contrast, transactional leadership is stabilityoriented leadership that promotes group activities within sectors of organizations rather than within entire organizations. It is a method of effectively managing the interrelationship between a leader and followers. In particular, it focuses on enhancing the productivity of a group, satisfying group members, and quantitative growth and performances. It also makes a point of economic rewards and socio-psychological inducements (Lee, 1994).

However, it is not easy to understand how local governors exercise their leadership through transformational and transactional leadership. This is because despite their conceptual differences, these leaders have a number of skills in common, which provide a behavioral direction for local governors to exercise leadership but do not guarantee leadership effectiveness. Thus, local governors must develop leadership skills to realize a vision for the local autonomy administration within their power and with a connection to the inter- and intraorganizational environment.

Leadership skills for local development may be connected with the maturity leadership within developmental psychology, and be considered in terms of knowledge, interorganizational behavioral skills and Interpersonal skills. First, successful leaders should develop and use knowledge to exercise leadership, even in uncertain and complex situations. Second, they should develop the behavioral skills required in special interorganizational relationships. Third, they should develop action skills to maintain their personality and act consistently, as well as effectively managing events within organizations. Table 1 shows the relationship between the common and distinct elements of leadership skills that are expected of local governors for effective leadership and local development.

\section{i) Knowledge-using Skills}

Knowledge-using skills are needed to establish a vision and strategy for local development. Both modes of leadership are based on knowledge of the peculiar local environment, as shown in Table 1 above. Transactional leadership is based on objective knowledge of the group and its capabilities, while transformational leadership requires subjective knowledge of the group. Thus, in presenting a policy and vision for local development, transactional leadership requires objective observation based on the capabilities of the group and organization, while transformational leadership requires personal aspiration and self-confidence based on the local governor's expertise. In particular, transactional leadership depends on the law and institution in the execution process. Thus, local governors try to apply related laws and institutions to resolve pending issues.

Table 1. Skills Required for Leadership Modes

\begin{tabular}{c|c|c|c}
\hline Sets of skills & Transactional leadership & Both modes of leadership & $\begin{array}{c}\text { Transformational } \\
\text { leadership }\end{array}$ \\
\hline $\begin{array}{c}\text { Knowledge } \\
\text {-using skills }\end{array}$ & Objective knowledge & Environmental knowledge & Subjective knowledge \\
\hline $\begin{array}{c}\text { Interorganizational behavioral } \\
\text { skills }\end{array}$ & Economic reward & $\begin{array}{c}\text { Communication } \\
\text { /negotiation }\end{array}$ & $\begin{array}{c}\text { Mass mobilization/ } \\
\text { specialists }\end{array}$ \\
\hline Interpersonal skills & Analytic approach & Self-confidence/intuition & Personality/traits \\
\hline
\end{tabular}


ii) Interorganizational Behavioral Skills

With respect to outer relations, local governors need behavioral skills to take the initiative in the situation of competition, conflict and cooperation and realize a policy and vision. Both modes of leadership require communication and negotiation when local governors express their ideas.

However, transactional leadership utilizes economic reward in pursuing the interests and goals of local government. They reward followers for their sincerity and favor and punish them for their insincerity and disfavor. On the other hand, transformational leadership tries to find a change of relation with outer organizations through an ability to integrate information and ideas provided by related organizations or specialists. It motivates follower to approach issues in a creative, innovative, and new way.

\section{iii) Interpersonal Skills}

Interpersonal skills are local governor's action skills that emerge in the process of leadership. They call on local governors to have selfconfidence in carrying out new affairs and to have intuition in a critical situation.

However, transactional leadership utilizes information analysis in crisis and risky situations in which the uncertainty and ambiguity of issues are higher. Thus, local governors require strong analytic reasoning capabilities. On the other hand, transformation leadership depends on personality and traits in dealing with uncertain, ambiguous and risky situations. Individual capability and experience before taking office are of great help in exercising leadership.

\section{METHOD}

\section{The Subject of Study}

This study is the local governors elected three times consecutively in the Korea's local govern- ment elections since 1995. Forty-four have been elected; among these, three are heads of upperlevel local governments and 41 are heads of lowerlevel local governments (14 in Cities, 14 in Kuns and 13 in $\mathrm{Ku}$ ). The subjects of the study are 13 third-term mayors elected in Cities.5) They are classified, by political party, previous career and education. First, distribution of political party shows that nine mayors $(69.2 \%)$ belong to the Grand National Party, 2 mayors $(15.4 \%)$ to the New Millennium Democratic Party and two mayors (15.4\%) are independent.

Second, former careers indicate that five mayors (38.5\%) were public officials, four of whom were appointed by the central government. Eight mayors $(61.5 \%)$ were politicians and most were public officials who had previous experience in administrative affairs. ${ }^{6}$ )

Third, 10 mayors $(76.9 \%)$ have more than college education, five of whom earned a masters or doctors degree, and one graduated from college during his term of office. Three mayors $(23.1 \%)$ highest education was high school graduation.

\section{Data Collection and Analytic Method}

\section{i) Data Collection}

Data was gathered by distributing questionnaires consisting of 27 items, as briefly shown in Table 2.7) They focus on mayors' personality, policies and businesses executed during their terms of

5) One of 14 mayors did not participate in this study.

6) Among the thrice-elected mayors who were appointed local governors are the mayors of Pyeongteak, Incheon Taebaek and Cheongju. The mayors of Pyeongteak and Incheon were previously county governors.

7) It took one month from June 24 to July 2002 for me to send questionnaires to secretary offices or planning departments and collect written answers from them, by mail or email.

6) The questionnaires were distributed to secretarial offices or planning departments. The information was collected between June 24 and July $24 \quad 2002$ and received by mail or email. 
Table 2. Main Questions

\begin{tabular}{|c|c|}
\hline & Main Questions \\
\hline $\begin{array}{l}\text { Local governor's personality } \\
\text { before inauguration }\end{array}$ & $\begin{array}{l}\text { - personality and quality of growth period } \\
\text { - personality of social activity period } \\
\text { - personality in local governor's preparation period }\end{array}$ \\
\hline $\begin{array}{l}\text { Policy vision, philosophy and executed affairs in } \\
\text { local governor's office }\end{array}$ & $\begin{array}{l}\text { - local governor's policy vision and philosophy } \\
\text { - main affairs carried out to resolve local pending issues }\end{array}$ \\
\hline $\begin{array}{l}\text { Local governor's roles in local autonomy } \\
\text { administration and local development }\end{array}$ & $\begin{array}{l}\text { - relationship with public officials } \\
\text { - relationship between local council and political parties } \\
\text { - relationship with administrative organizations } \\
\text { - relationship with the press } \\
\text { - relationship with local residents } \\
\text { - relationship with special interest groups } \\
\text { - relation to electorate and others }\end{array}$ \\
\hline
\end{tabular}

Table 3. Number of Cases on Local Governor's leadership

\begin{tabular}{c|c|c|c|c|c}
\hline Nu. of Cases & 7 & 6 & 5 & 4 & 2 \\
\hline \hline Local Government & Gumi & Taebaek Chungju & $\begin{array}{c}\text { Incheon Kangnung } \\
\text { Gimje }\end{array}$ & $\begin{array}{c}\text { Sokcho Samcheok } \\
\text { Gimcheon Sangiu }\end{array}$ & $\begin{array}{c}\text { Pyeongteak Jinhae } \\
\text { Milyang }\end{array}$ \\
\hline
\end{tabular}

office, and the mayors' roles. More specifically, the questionnaire asked about their family lives, school and society before inauguration; their personal influences in the formation of their valucs; and the enhancement of their leadership as mayors after inauguration. Second, the questionnaire asked about a vision and philosophy that they established during their term of office and how they resolved difficulties dealing with important local affairs. Third, the mayors were asked how they exercised their leadership for successful local development among the local council, upper-level institutions, the central government, civic organizations, the press and citizens' complaints.

\section{ii) Analytic Method}

The analysis is based on looking closely at local governors' responses to the 27 items. It excludes projects and programs that the respondents did not specifically describe but enumerated in their responses. Based on these selected cases, this study investigates how local governors worked out a vision and strategy in a variety of situations, how they executed them and what they achieved. In particular, it examines how knowledge, interorganizational behavioral and interpersonal skills are connected.

According to the criteria and method of analysis, 56 cases of local governors' leadership were selected. The most results were obtained from Gumi, and the fewest cases in Pyeongteak, Jinhae and Milyang. Table 3 shows the number of cases sclected from Cities.

\section{ANALYSIS AND RESULTS}

\section{Analysis of Knowledge-using Skills}

Local governors put knowledge of the local environment ahead of all else in the process of working out a strategy for local development. They try to promote local economy and raise residents' standard of living by using knowledge of the local environment. Above all, they work out a strategy for local development to construct an innovative 
urban environment. Then they try to solve pending local issues by expanding the urban infrastructure.

First, local governors using knowledge of the local environment conduct local affairs with a strong belief in local development. Environment knowledge assumes two characteristics depending on the creation of direct additional value. In order to commercialize the knowledge of a specific local environment, local governments develop strategies for local events such as the Incheon World Ceramic Exposition, the Gangweon International Tourism Expo 1999, the Samcheok World Cave Expo 2002, the Chungju World Martial Arts Festival, the Gimje Horizon Festival and the Sangiu Bicycle Festival. Such local festivals are excellent local innovations because they realize the potential of local development, promote and systemize a unique local environment, culture and international cultural exchanges, and create various facilities. The local festivals in Chunju, Incheon, Gimje and Sangju, in particular, showed civic harmony and unique traditional culture. Moreover, the Horizon Festival in Gimje was a cultural festival on rice in order to an increase the income of farmers by publicizing 'horizontal rice' produced in Gimje's during the festival. In addition, local governors made the most use of their knowledge of the environment as stimulus for the local economy. Gangnung's mayor developed the area where a North Korean submarine infiltrated into a tourist resort by connecting it to Jungdongjin. Taebaek's mayor renovated the city as an old coalmining city and a future-oriented tourism leisure sports city. Gumi's mayor enacted various policies to utilize the characteristics of the old export industrial zone in an effort to renovate Gumi's industrial complex into a high- tech industrial complex.

Second, local governors tried to find alternative plans by observing phenomena in the process of resolving pending issues. Gimcheon had a population of about 150 thousand and about 1,400 public officials. The number of the latter is too large, and it resulted in too great a budget item. The mayor objectively observed the city's strengths, which he linked to local development. That is, he discovered how to build up the infrastructure by reducing human resources and the budget. As a result, the local government reduced routine expenditures and reduced the number of public officials by 320 , which followed the central government' structural adjustment. The city government saved $\backslash 55$ billion and has a sports complex and a culture and art center.

Third, local governors developed programs for local development based on their expertise. Many students from Incheon had left the city for larger cities to study in a better environment, or had given up their studies because of economic difficulties. As a part of a solution to this problem, the mayor established an association to raise scholarship funds, which developed from a movement to cultivate men and women of ability and talent to become a milestone in local development and enhancement of citizens' quality of life. Fourth, local governors presented solutions to pending local issues as a vision and used institutional knowledge to carry it out. Taebaek proposed a vision to build an environmentally friendly tourism leisure area in its natural environment on a plateau to promote the local economy, which was depressed after the closure of coalmines. Eventually, a casino business where even domestic tourists can be admitted was established, and the city spent some of the resultant revenue to the regions where coalmines closed.

\section{Analysis of Interorganizational Behavioral Skills}

The characteristics of a local governor's interorganizational behavioral skills are found in the process of securing the administrative and political potential to commercialize knowledge of the environment. Actually, although local governors work develop a strategy for local development, lower- 
level local governors have considerable difficulty implementing their strategies, if they do not have sufficient administrative and political potential. In addition, the task may be impossible if they lose in a competition with an adjacent local government or face a strong opposition from the local council, civic organizations and public opinion.

First, local governors try to gain cooperation and support from the central government. The governors' interorganizational behavioral skills are prominent when they try to secure government affairs for their local development. Local governors make every effort to win cooperation from, and maintain a close relationship with the central government in order to enhance feasibility of developing their visions. Interorganizational behavioral skills were prominent particularly in Pyeongteak, Incheon, Gangnung, Taebaek, Sokcho, Gimje, Gumi, Jinhae and Milyang. Pyeongtaek's mayor connected the national harbor development project to the urban development of Pyeongteak in the development and operation of Pyeongteak harbor. Incheon's mayor organized a council of 10 mayors and lower-level local governors as bloc of eastern Gyeonggi Province in 1995, and they stood together against the national government lobby for the revision of the Improvement Plan Law of the Metropolitan Area, which prevented Incheon's local development. Gangnung's mayor developed a plan to promote a tourist resort by connecting the infiltration area of a North Korea's submarine to Jungdonjin, and made possible the construction of an exhibition center for unification security with the hclp of the Office of the Prime Minister, the Ministry of National Defense and Navy Headquarters. Taebaek's mayor called on the national government to enact a special law to support the development of abandoned mine areas and reached an agreement with the central government on coal price subsidies, promotion of alternative industries and recruitment for training institutes. In the process, he promoted group demonstrations and a signature movement to enact a special law. Sokcho's mayor, with the help of the Ministry of Maritime Affairs and Fisheries and the Ministry of Unification, opened a route to Mt. Baekdo and an international tourist terminal to lay the foundation for the city's development as an East Sea hub port. Jinhae's mayor promoted an industrial complex exclusively for small and medium-sized enterprises through a series of discussions with the Ministry of Commerce, Industry and Energy, the Small and Medium Business Administration, Gyeongsangnamdo, and the Small Business Corporation. Gimje's mayor successfully acquired funds from the national budget to construct a community for scnior citizens. Gumi's mayor worked closely with related departments of the central government on the promotion of the Industrial Complex 4 in the city. Milyang's mayor presented a bill to the National Assembly five times, a constitutional petition twice for the revision of the Water Law in collaboration with 72 local governors.

Second, local governors' communication/negotiation skills are prominent when their projects face strong opposition from local residents, and they try to unravel conflicts. As mentioned above in leadership skills, local governors try to expand local infrastructures for local development. In particular, they face severe conflicts when they try to select a location for facilities such as land reclamation, water discharge facilities and crematoriums. Conflict generally stems from residents' poor understanding of administrative affairs. Local governors foster communication and negotiation in the interest of the entire community and conclude mutual agreements based on rational rewards. The main conflicts involved land reclamation in Incheon, Gangnung, Gimje and Gumi, and water discharge facilities in Gangnung and Gimcheon, and a highvoltage power transmission tower in Gumi. Most local governors face resistance for 2 or 3 years when they try to locate unpopular facilities. Through diverse publicity activities such as public 
hearings governors try to explain the positives and negatives of their projects to their constituencies, Gumi's mayor found a solution in collaboration with residents where there was strong opposition to the a land reclamation project in Gupo. In addition, the mayor proved a good mediator between labor and management.

Third, local governors overcome critical situations, gain the upper hand in negotiations negotiation with other outer bodies, institutionalize the participation of local residents and cooperate with other local governments. Taebaek's mayor prevented the central government from nationalizing Mt. Taebaek Provincial Park in collaboration with local social organizations and, in collaboration with other local governments and a local legislator, persuaded the central government enact a special law to support the development of abandoned mine areas. Incheon's mayor cooperated with other local governments for a revision of the Improvement Law of the Metropolitan Area.

Fourth, local governors make the most use of economic rewards to recruit large-scale local development projects with high value added capital and technology. Among the representative projects is the Oriental Medical Resources Industrial Complex. Sangju's mayor worked with local residents and public officials to recruit the group and won them over by offering specific conditions such as building sites and securing working capital.

Fifth, local governors raise the consciousness of local communities in the interest of individuals and local bodies. Such leadership is found in Incheon, Sokcho, Gumi and Milyang. Incheon's mayor established and operated an association to raise scholarship funds' and obtained excellent results for improving the educational environment and atmosphere of study. Sokcho's local government proposed the opening of a route to Mt. Baekdu to the central government, local businesspeople and civil organizations, and asked for support for maintaining business and cultural exchange for 10 years with Hunchun City in China. Gumi's mayor established a 'city development planning team' to develop a strategy to change Gumi's industrial complexes to world class high-tech industrial complexes and constructed a framework in which local businesspeople could participate. He established the Gumi Trade Exhibition Center in Shenyang, China to open up new export markets and recruit foreign businesses. He also tried to find various international exchanges and cooperative activities such as a joining the IULA, and inviting foreign ambassadors to visit the city with a view to investment. With local residents' help, a signature movement and presentation of a petition to the central government, Milyang's mayor made possible the construction of an expressway between Daegu and Busan. Sixth, local governors seek information and ideas from specialists. The local governments of Gangnung, Cheonju, Gimje and Gimcheon all used outside experts. Gangnung's mayor formed a consortium with a university and developed policies for local development. Cheonju's mayor sought fresh ideas from professors, cultural artists and professional representatives, and Gimje's mayor organized professional structure teams as well as special execution teams. Gimcheon's mayor not only invited outer specialists and ran a room for policy research, but also held a three-lack policy form. Gumi's mayor formed a future design team of academics and connected fresh ideas to local policies.

\section{Analysis of Interpersonal Action Skills}

The execution of local development is possible when knowledge of a local environment is accompanied with personal zeal and self- confidence. Local governors carried out local development with strong self-confidence as well as with sufficient knowledge of the environment. In particular, when they faced strong opposition, or an uncertain or a critical situation, they express the self-confidence that they would not fail. When they 
tried to introduce an event-style local festival in Incheon, Sokcho, Samcheok, Cheonju, Gimje and Sangju, they encountered opposition and skeplicism from local council, citizens, public officials and the central government. However, they realized their aspiration with self-confidence. For example, Gimje's mayor accomplished his program with his positive attitude and determination. Gimje previously spent over 200 million of their budget every year to celebrate Citizens' Day. The mayor judged that the event was wasteful and useless for civil harmony and local development. He replaced it with a 'Horizon Festival' that exhibited Gimje's distinctiveness. He faced considerable difficulties and objections, but carried established it with his belief that the festival would contribute to civil harmony, local publicity and increased revenue. It was eventually singled out by the central government as an excellent example of a cultural festival.

On the other hand, local governors overcome crisis rationally and analytically when situations work against them. Samcheok's mayor faced opposition from local council, specialists and the public when he tried to restore Hujin station near Samcheok Beach. He won the publicity war against Korea National Railroad by presenting various promising perspectives.

Finally, local governor's former careers were helpful in carrying out their vision for local development. Gimje's mayor, who had worked for a local councilor and aide to a member of the National Assembly, had a regular meeting with the local council and maintained a close relationship with it. For example, Jeonju's local government and council stood together against the central government, which had planned to construct a new airport in Jeonju. Samcheok's mayor and Gangnung's mayor, once National Assembly member, used influential politicians in the central government and assembly to resolve local difficulties, when the city wanted to enact large local development projects or gain a larger share of the central government's budget for the community. Gangnung's mayor also benefited from his career as a former National Assembly member. He was supported by the Ministry of Commerce, Industry and Energy when the city and Korea Electric Power Corporation were involved in reward issues for the pollution of Namdaechon, and supported by the Ministry of Construction and Transportation over the construction of a road to Gangnung High-tech Industrial Park. Likewise, the mayors of Pyeongteak, Incheon, Taebaek and Cheonju each achieved long-cherished local projects on the basis of their ample experience as former public officials. Pyeongtaek's mayor displayed his capacity to unravel complicated matters regarding local integration and development.

Incheon's mayor, who majored in history in college, had ample experience in the main central government departments after his success in the National Administration Exam. In particular, his career as a director of Daejon Expo '93 contributed to holding the World Ceramic Exposition in 2001. Cheonju's mayor worked for the Ministry of Home Affairs and Cheongwadae in the office of the president. In addition, he worked as Yongwol's local governor and a planning director of Chungcheongnam-do. These careers were instructive in controlling an administrative body and unraveling local financial difficulties.

\section{CONCLUSION: DERIVATION OF TYPES OF LEADERSHIP}

So far, this study has analyzed the effect of local governors' leadership on local development. In particular, local governors took into account the leadership skills that they exercised during their first and second terms of office. Table 4 summarizes the 13 local governors' leadership skills, and classifies transformational and transactional leadership based on Bass's (1985) two-factor model. It shows that 10 mayors preferred trans- 
Table 4. Connection between Leadership Skills and Types

\begin{tabular}{|c|c|c|c|c|c|c|c|c|c|c|}
\hline \multirow[b]{2}{*}{ City } & \multicolumn{3}{|c|}{ Knowledge-using Skills } & \multicolumn{3}{|c|}{$\begin{array}{c}\text { Interorganizational Behavioral } \\
\text { Skills } \\
\end{array}$} & \multicolumn{3}{|c|}{ Interpersonal Action Skills } & \multirow[b]{2}{*}{$\begin{array}{l}\text { Types of } \\
\text { leadership }\end{array}$} \\
\hline & $\begin{array}{c}\text { Objective } \\
\text { Knowledge }\end{array}$ & 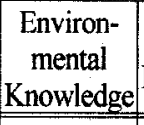 & $\begin{array}{c}\text { Subjective } \\
\text { Knowledge }\end{array}$ & $\begin{array}{c}\text { Economic } \\
\text { Reward }\end{array}$ & $\begin{array}{l}\text { Negoti- } \\
\text { ation }\end{array}$ & $\begin{array}{c}\text { Mass/Spe- } \\
\text { cialists }\end{array}$ & $\begin{array}{c}\text { Analytic } \\
\text { Approach } \\
\end{array}$ & \begin{tabular}{|c|}
$\begin{array}{c}\text { Self-confi- } \\
\text { dence/Self- } \\
\text { esteem }\end{array}$ \\
\end{tabular} & Personality & \\
\hline Pyeongteak & & & & & *** & & & & * & $\begin{array}{c}\text { Transformational } \\
\text { leadership }\end{array}$ \\
\hline Incheon & & * & $* *$ & $*$ & $* *$ & $* *$ & & $*$ & $*$ & $\begin{array}{c}\begin{array}{c}\text { Transformational } \\
\text { leadership }\end{array} \\
\text {. }\end{array}$ \\
\hline Gangnung & & $*$ & & $*$ & $* *$ & $*$ & & $*$ & * & $\begin{array}{c}\text { Transformational } \\
\text { leadership }\end{array}$ \\
\hline Taebaek & & $* * *$ & * & & $* * *$ & $* * *$ & & $* *$ & * & $\begin{array}{c}\text { Transformational } \\
\text { leadership }\end{array}$ \\
\hline Sokcho & & $* * *$ & & & $* * *$ & & & $* *$ & * & $\begin{array}{c}\text { Transformational } \\
\text { leadership }\end{array}$ \\
\hline Samcheok & & $* * *$ & & & $* * *$ & * & $*$ & $* * *$ & $*$ & $\begin{array}{c}\text { Transformational } \\
\text { leadership }\end{array}$ \\
\hline Cheonju & & $* *$ & & $*$ & $* * *$ & $*$ & & * & $*$ & $\begin{array}{c}\text { Transformational } \\
\text { leadership }\end{array}$ \\
\hline Gimje & & $* *$ & & & $* * *$ & $*$ & & $*$ & $*$ & \begin{tabular}{|c|}
$\begin{array}{c}\text { Transformational } \\
\text { leadership }\end{array}$ \\
\end{tabular} \\
\hline Gimcheon & ** & & & & & $*$ & & & & $\begin{array}{l}\text { Transactional } \\
\text { Leadership }\end{array}$ \\
\hline Gumi & & $* *$ & & & $* *$ & $* * *$ & & & & $\begin{array}{c}\text { Transformational } \\
\text { leadership }\end{array}$ \\
\hline Sangju & & $*$ & & $* *$ & $* *$ & & & $*$ & & $\begin{array}{c}\text { Transactional } \\
\text { Leadership }\end{array}$ \\
\hline Jinhae & & & & * & $* *$ & & & & & \begin{tabular}{|c|}
$\begin{array}{c}\text { Transactional } \\
\text { Leadership }\end{array}$ \\
\end{tabular} \\
\hline Milyang & & & & & * & $* *$ & & & & $\begin{array}{c}\text { Transformational } \\
\text { leadership }\end{array}$ \\
\hline
\end{tabular}

Note: ${ }^{*}$ indicates the degree of related leadership skills.

For example, ${ }^{* * *}$ is larger than ${ }^{* *}$ and ${ }^{* *}$ is larger than $*$.

formational leadership to transactional leadership whereas three mayors preferred transactional leadership to transformational leadership.

Bass's transformational and transactional leadership represent change-oriented and stabilityoriented leadership, respectively. Oh (1999) claims that increased transformational leadership will be required, considering a rapid change of the administrative environment and actual situations of organizational society. The results revealed that local governors used the characteristics and skills of change-oriented leadership rather than stabilityoriented leadership.

However, similar characteristics are found in the three types of leadership skills. Out of them, both modes of leadership were excrcised better than were transformational and transactional leadership. Specifically, the use of knowledge of the environment was the preferred knowledge- based skill. Negotiation was the preferred interorganizational behavioral skills, and self-confidence and selfesteem were the preferred concerning interpersonal action skills. This suggests that local govemors realized local development by a proper combination of transformational and transactional leadership.

Taebaek, Sokcho and Samcheok used the knowledge of the local environment more than the other 
cities. This indicates that these three local governments made the most use of their environmental peculiarities to commercialize natural resources. In particular, Taebaek and Samcheok developed their natural resources in an environment-friendly way to promote the local economy, which was depressed after the closure of coalmines. In addition, the mayors and won cooperation and support from the central government with a firm belief that they could activate their local economy by utilizing knowledge of their environment.

Second, the mayors of Taebaek, Sokcho, Samcheok, Cheonju and Gimje made more use of communication/persuasion/negotiation than the other cities. When they connected knowledge of the local environment to local development strategies, they convinced the opposition and won administrative, political and financial cooperation and support by their negotiations with the upper-level and central governments.

Third, the interpersonal action skills, selfconfidence and self-esteem were more prominent in Taebaek, Sokcho and Samcheok than in the other cities. In particular, Taebaek's mayor made every effort to develop the local environment in an environmentally friendly way with a firm belief that he could renovate the economically depressed mining city into a tourist leisure area. On the other hand, Sokcho's mayor executed his policies based on principle.

\section{Bibliography}

\section{non-Korean}

Ammeter, Anthony P. 2002. Toward a political theory of leadership, The leadership quarterly, 13, $751 \sim 796$.

Bass, B. M. 1985. Leadership and performance beyond expectations, New York, NY: Free Press

Bass, B. M. \& Avolio, B. A. 1994. Improving organizational effectiveness through transformational leadership. Thousand Oaks, CA: Sage.

Burns, J. M. 1978. Leadership. New York, NY: Harper Row.

Creamer, David de. 2001. Intergroup and Intragroup Aspects of leadership in social Dilemmas: A Relational Model of Cooperation, Journal of Experimental Social Psychology, 38, 126 136 .

Denhardt, R. B \& W. H. Stewart, eds. 1992. Executive leadership in the public service, Tuscaloosa, Al: Univ. of Alabama.

Morgan, D. R. \& Watson. 1995. Policy leadership in Council-Manager Cities: Comparing Mayor and Manager, Public Administration Review, 52(5).

Schein, E. H. 1997. Organizational Culture and leadership, 2nd ed. San Francisco: Jossey-Bass Publishers.

Svara, James H. 1994. Facilitative leadership in local government: lessons from successful mayors and chairpersons, San Francisco: Jossey-Bass Publishers.

Yukl, G. 1994. Leadership in organizations. London: Prentice-Hall.

\section{Korean}

Kim, Kwang-Ju, 1995. A Behavioral Research on Korean Inter Governmental Relationship Behavior. Korean Public Administration Review, 29(4), $1171 \sim 1191$.

Kim, Byong-Jun. 1994. The Political Poles of Elected Chief Executives of Local Governments. The Journal of the Korean Association for Local Administration, 9(1), 1 16 .

Kim, Byung-Kuk. 1996. The Change of Relationship between Local Governor and Council since Local Election '95. The Journal of the Korean Association for Local Administration, $39,1 \sim 38$

Kim, Ho-Jung. 2001. The Relationship of Transfor- 
mational Leadership and Transactional Leadership, and the Desirable Model of Leadership. Korean Policy Studies Review, 10(3), 8 $7 \sim 107$.

Park, Jong-Min \& Lee, Jong-Won. 2002. Crisis of Local Democratic in Korea: A Challenge and Question. Seoul: Nanam Publishing Company.

Ahn, Chung-Si. 2002. Local Autonomy and Democratic in Korea: A Performance and Question on 10 years. Seoul: Nanam Publishing Company.

Seong, Kyung-Ryung. 1995. A Study on the Role of the Heads of Local Governments. Korean Political Science Association Review, 29(4), $347 \sim 371$.

Oh, Suck-Hong. 1999. Organization Theory. Seoul: Pakyoungsa.

Lee, Jong-Bum. 1994. Administrators on the Transformation Ear. Seoul: Nanam Publishing Company.

Lee, Seung-Jong. 1998. Determinants of Mayoral Leadership. Korean Public Administration Review, 32(1), 147 161.

Lee, Chang-won. 1999. An Empirical Study on the Leadership Styles of Chief Executives in Korean Local Governments \& their Effectiveness. Korean Public Administration Review, 33(3), $273 \sim 286$.

Lee, Chang-Won. 2000. An Empirical Study on the Effects of Tiers of Local Governments on the Leadership Styles of Chief Executives in Korean Local Governments \& their Effec- tiveness. Korean Public Administration Review, 34 (2), $139 \sim 160$.

Lee, Chang-Won \& Kim, Ho-Jung, Park, HeeBong, Ralph W. Adlder. 2003. Transformational Leadership behaviors \& Leadership Effectiveness of Chief Executives in Local Governments: Compares between Korean \& New Zealand. Korean Public Administration Review, 37(1), 19 -36.

Lee, Hak-Jong. 1995. Organizational Development Theory, Seoul: Bobmunsa.

Lim, suhng-Bin \& Cho, Suck-Ju. 1996. A Study on the Institution Improvement Alternative Plan for the desirable roles of Elected Local Governors, Korean Research Institute for Local Administration, Report Paper.

Chun, Chun-Kil. 1994. Economic Leadership of President. Seoul: The Korean Economy Daily.

Choi, Chang-Su. 2000. A Study on the Policy Process and Leadership of Elected Mayors in Korea Local Government. Korean Research Institute for Local Administration report, Report Paper.

Lee, Sang-Pal \& Jung Byung-Kul. 1999. An Analysis of Local Government Chiefs Impression Management Strategy in Policy Process. Korean Public Administration Review. 33(3), $287 \sim 308$.

Knowledge Center for Public Administration and Policy. 2002. Leadership of Local Governors. I-IV, Seoul: Nanam Publishing Company. 